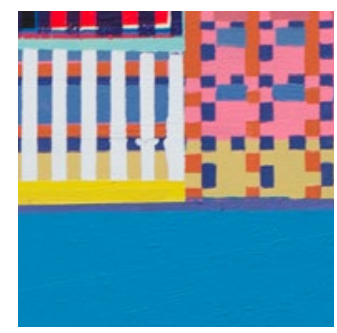

\title{
Noticia sobre Marc Augé, destacado visitante en Montevideo, en octubre 2017
}

\author{
Sonnia Romero Gorski \\ Instituto de Antropología, Facultad de Humanidades \\ y Ciencias de la Educación. sromero@fhuce.edu.uy
}

\begin{abstract}
"El etnólogo se encuentra siempre de viaje, aunque trabaje en las afueras de una ciudad de su país, en la medida que es un viajero de lo interno, que viaja entre estados anímicos, entre dos maneras de pensar, entre el futuro texto y el texto ya redactado, entre un Antes y un Después." (Augé, M. 2007: 70. Por una antropología de la movilidad, Ed. Gedisa, Barcelona)
\end{abstract}

Entre el 10 y el 19 de octubre del 2017 Marc Augé estuvo en Montevideo, respondiendo a una invitación que le hiciera el proyecto Memoria Futura (proyecto ganador de Presupuesto Participativo de la IM), conjuntamente con la FADU, Facultad de Arquitectura Diseño y Urbanismo, con adhesión de la FHCE, Facultad de Humanidades y Ciencias de la Educación, con apoyo de la Embajada de Francia y de la Alianza Francesa.

Esta visita y participación de Marc Augé en diferentes actividades en nuestro medio, requiere una breve presentación sobre la importancia de su trayectoria, de su obra siempre creciente.

Es interesante acercarse a su labor de etnólogo, antropólogo y escritor, desde una perspectiva de conocimiento, de lectura de sus textos a lo largo de un tiempo académico prolongado y fecundo. Sus trabajos han sido leídos e incluidos en el acercamiento teórico, en la formación, de

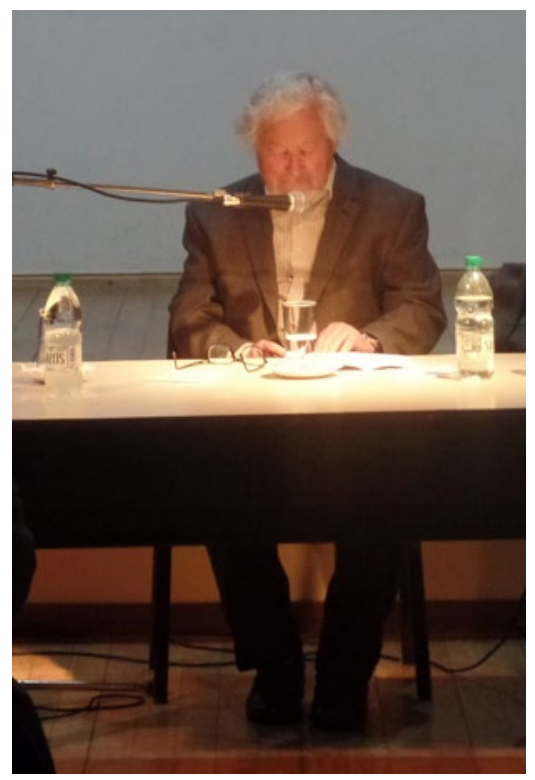


varias generaciones de estudiantes de grado y de posgrados en antropología, sociología, historia, psicología, urbanismo, entre otros.

Marc Augé sostuvo durante tiempo varias funciones dentro del quehacer académico de Francia: como director de la École des Hautes Études en Sciences Sociales, EHESS, de Paris (1985-1995), como director de Estudios en la misma EHESS, como miembro fundador del Centro de Antropología del Mundo Contemporáneo, como investigador del CNRS y como responsable de Seminarios, pasando también a ser una presencia activa (hasta la fecha) en Congresos, Coloquios internacionales, en Conferencias en Universidades en el mundo entero.

En esa dinámica de fuerte compromiso académico y vinculación con el mundo, Marc Augé ya había estado en Montevideo - en una muy breve estadía -, como invitado a la VI Reunión de Antropología del MERCOSUR, en los días 16, 17 y 18 de noviembre del 2005.

En aquella ocasión expuso en el Paraninfo de la UDELAR donde tuvieron lugar los Simposios de la VIRAM. En el Simposio II habló sobre "Construcción de bloques regionales, experiencias de América Latina y Europa”, y en el Simposio III fue parte del "Homenaje a la obra de Gérard Althabe". En: Libro de Conferencias y Relatorías, VI RAM. Identidad, Fragmentación y Diversidad, Montevideo, 2006.

Retomando su trayectoria de forma cronológicamente más ordenada, hay que señalar que Marc Augé tuvo la experiencia de investigaciones en sociedades africanas, de las que tomaría grandes temas vinculados a la producción de sistemas simbólicos, a las figuras de culto dentro de la diversidad de panteones de las religiones africanas. El estudio de ese complejo panorama lo llevó a profundizar en la categoría de los llamados paganismos, a consolidar la tipología de tan importante capítulo de la religiosidad, presentes tanto en el pasado como en época contemporánea, y no solo en sociedades africanas sino también en países latinoamericanos que conservan y van transformando el acervo de ancestros afrodescendientes, desde Haití a Brasil, llegando hasta Uruguay y Argentina. Observó la producción dinámica de figuras complejas dentro de la religiosidad de base africana, con aproximaciones sincréticas a religiones monoteístas.

Junto con Max Weber y Mircea Eliade, Marc Augé es autor imprescindible en bibliografías para entender la génesis y producción de simbolismo dentro del corpus de diferentes religiones, para notar la recurrencia de figuras en rituales, en diferentes continentes, “....así pues el paganismo es, en primer lugar, todo lo contrario del cristianismo; (...) Nunca es dualista, y no opone el espíritu al cuerpo ni la fe al saber. No concibe la moral como un principio externo a las relaciones de fuerza y de sentido que traducen las vicisitudes de la vida individual y social. Postula una continuidad entre orden biológico y orden social, continuidad que, por una parte, relativiza la oposición entre la vida individual y la colectividad en la que se inserta y, por otra parte, tiende a convertir todo problema individual o social en un problema de lectura, pues postula que todos los acontecimientos constituyen signos, y que todos los signos tienen sentido. La salvación, la trascendencia y el misterio le son esencialmente ajenos. Como consecuencia, acoge la novedad con interés y espíritu de tolerancia; siempre dispuesto a prolongar la lista de dioses, concibe la suma y la alternancia, pero no la síntesis." (Augé, 1993:17)

Sobre esta inspiración pueden construirse abordajes, interpretaciones de fenómenos religiosos observables en escenarios locales, regionales, permitiéndonos registrar la profundidad histórica, étnico-cultural de una diversidad de creencias, que impregnan soterradamente nuestra sociedad contemporánea. En esta línea constituyen un aporte 
importante, siempre vigente, títulos como (Augé, M. 1996). Dios como objeto. Símbolos-cuerpos-materias-palabras. Editorial Gedisa, Barcelona, [1988, Flammarion] y (Augé, M. 1993) El genio del paganismo. Muchnik Editores, Barcelona. [1982, Éditions Gallimard]

Como ya se dijo más arriba, Marc Augé fue uno de los fundadores del Centre d'Anthropologie des Mondes Contemporains, verdadero centro de producción de conocimiento, de investigaciones, de encuentro de importantes figuras que coincidieron en un proyecto notable de renovación de la Antropología, trayéndola hacia lo cotidiano, lo contemporáneo, los mundos urbanos, los espacios, la movilidad, la mundialización, la globalización, los mercados, en un despliegue de interrogación científica sobre lo particular más cercano y lo global más lejano.

En dicho Centro formaron cuerpo académico prestigiosos investigadores, junto a Marc Augé, Gérard Althabe, Jean Bazin, Michele de La Pradelle, Alban Bensa, Jonathan Friedman (invitado en la EHESS); desde allí salieron no solo múltiples publicaciones, sino seminarios, tesis, proyectos conjuntos entre varios países. La línea que se impulsó sigue reflejándose en los sucesivos títulos que Marc Augé ha publicado, desde 1987 a la fecha. La obra paradigmática de aquella nueva propuesta de investigaciones etnográficas, antropológicas, en terrenos conocidos y cotidianos es El viajero subterráneo. Un etnólogo en el metro, (Augé, M. 1987, Ed. Gedisa [1987 ed. Hachette])

Desde allí se va a interesar en temas de lo contemporáneo: relaciones contextualizadas en la ciudad genérica, en la ciudad-mundo, en los espacios vacíos. Explorando, observando, sistematizando, llega a descubrimientos a los que nombra de manera provocativa como fenómenos de ausencia: los No-lugares que sugieren una Antropología de la Soledad, por diferencia del Lugar Antropológico donde el vínculo y el reconocimiento producen condiciones para una sociabilidad de proximidad, culturalmente significativa.

Desde la formulación de esas categorías canónicas, por más discutidas, aceptadas o rechazadas, que hayan sido, ha crecido el interés por pensar el sentido que se coloca y el sentido que se busca en los espacios habitados, transitados, frecuentados o evitados. El movimiento atraviesa ciudades, filamentos urbanos, lleva poblaciones en fuga, en búsqueda de refugio o en procura de esparcimiento turístico en paisajes extranjerizantes. El turismo, o el viaje, será también uno de los temas que Marc Augé va a jerarquizar con abordaje e interpretación teórica, problematizando efectos materiales sobre los territorios-destinos turísticos. (Augé, M. 1998. El viaje imposible. El turismo y sus imágenes. Ed. Gedisa [1997, Éditions Payot-Rivages]).

A medida que avanza en una observación y registro de fenómenos en diferentes contextos, Marc Augé va produciendo no solo obras, sino categorías que permitan captar la inmensidad de múltiples factores interrelacionados en dimensiones espaciales y temporales, el tiempo, las transformaciones histórico-culturales. La sobremodernidad (surmodernité) apareció así en toda su complejidad: aceleración del tiempo, achicamiento del espacio, acumulación de imágenes, mensajes, predominio de la tecnología.

Advierte acertadamente cómo se coloca el antropólogo ya no frente a un pueblo o un barrio, abarcables en la observación, sino frente a fenómenos enormes, globales: "el método etnológico no tiene como objetivo final al individuo (como para la psicología), ni la colectividad (como para la sociología) sino la relación que permite pasar del uno al otro. Las relaciones (de parentesco, relaciones económicas, relaciones de poder) deben ser, en un conjunto cultural dado, concebibles y gestionables. Gestionables porque toman cuerpo en instituciones que las ejecutan (la familia, el Estado, la iglesia y muchas otras a distintas escalas). Concebibles ya que tienen cierta evidencia a los ojos 
de los que se reconocen en una misma colectividad; en este sentido son simbólicas (...) es el nexo lo que es simbólico". (www.ddooss.org/articulos/textos/Marc_Auge.htm).

El trabajo y la reflexión con vocación cada vez más abarcativa, con interrogantes y hasta preocupación por la dimensión de las transformaciones cuyas resoluciones o consecuencias, que el antropólogo puede visualizar en un futuro casi previsible, puede seguirse en los títulos de su bibliografía. Lleva la reflexión por muchos lugares, y no-lugares, pero vuelve siempre a la centralidad antropológica de una revolución contemporánea: la urbanización del mundo (bajo influencia de estudios del demógrafo Hervé Le Bras).

Finalmente, aunque no es menor como aporte al mundo de las ideas, a las humanidades, Marc Augé se ha preocupado por el trabajo sobre la Escritura, cómo relacionarse con la comunicación, con los textos, incluso con la literatura. En este campo hizo aportes y experiencias de interés,

Ésta es una aproximación sintética a una trayectoria muy prolífica, con obra e influencia muy destacada. Un intelectual francés de gran estilo y tradición. Sus colegas de la EHESS de Paris lo homenajearon en el 2008 con la publicación de un número especial de la revista L'HOMME, 546 páginas dedicadas enteramente a su obra.

Situándonos en el ámbito local es ahora importante registrar, destacar, que se le hicieron reconocimientos significativos, marcando por un lado su vínculo con el conocimiento en términos académicos y por otro una muy difundida identificación con la obra del antropólogo. La sienten próxima también arquitectos, artistas, gestores culturales, vecinos de barrios o locales rehabilitados, jóvenes militantes de asociaciones por un uso responsable de las ciudades, entre otros. Es decir que la obra de Marc Augé ha rebasado los límites de las instituciones para llegar a los ciudadanos del mundo, reales destinatarios.

El día 17 de octubre se le entregó del Título de Profesor Ad Honorem, por parte del decano G. Scheps de FADU y el Decano A. Rico de FHCE, en presencia del Rector de la Universidad de la República R. Markarian. Sala del Consejo de FADU.

El día 18 de octubre, en el Hotel Esplendor, lo recibieron integrantes del Proyecto Memoria Futura, Barrio de las Artes, artistas que participan en el mismo, así como miembros de una Asociación de Defensa del uso de la bicicleta quienes le ofrecieron una escultura, un premio al BICITANTE ILUSTRE. Muy simpático juego de sentidos que refería a su condición de visitante y defensor de la "bici" (Elogio de la bicicleta, M. Augé, 2009, Ed. Gedisa)

Los integrantes de la Academia y público variado estuvieron muy presentes en las Conferencias que dio el día 13 de octubre en FADU y el mismo día en FHCE, el día 14 en la Activación de la Casa Mario, en Ciudad Vieja, y el día 17 en la Alianza Francesa.

En este Dossier reproducimos la totalidad de su exposición en el Salón de Actos de la Facultad de Humanidades y Ciencias de la Educación, en el marco de las Jornadas de Investigación 2017. Ese día, la presentación de la figura de Marc Augé estuvo a cargo del Sr. Decano, Alvaro Rico por la FHCE y de Sonnia Romero, del Instituto de Antropología. 